\title{
A Cultural Repertoire of Practices in Doctoral Education
}

\author{
Karri A. Holley \\ University of Alabama, \\ Tuscaloosa, AL, USA
}

\section{kholley@bamaed.ua.edu}

\begin{abstract}
Culture is frequently characterized as a concept with which students must contend to succeed in college as well as a distinct, consistent characteristic of the institution. This article focuses on culture as an active repertoire of behaviors, beliefs, and actions that include symbols of meaning and cultural practices selectively used by group members. Using the example of doctoral student socialization, the study considers how students organize and interpret culture, rather than simply how culture organizes individuals. Implications for future thematic research regarding culture are discussed.
\end{abstract}

Keywords: doctoral student socialization, academic disciplines, culture, research practices, qualitative inquiry

\section{Introduction}

Culture has become an exceedingly common component of higher education research (i.e., Tierney, 1988; Valimaa, 1998). Organizational theorist Edgar Schein defined culture as "a set of taken for granted assumptions," concluding that "culture is ubiquitous... it covers all aspects of group life" (1988, p. 10). Among the range of topical areas, higher education researchers have focused on the impact of the college culture on undergraduate student experiences (Bertram Gallant, 2007; Love, 1997), the relationship between institutional culture and behavior (Kezar \& Eckel, 2002; Thornton \& Jaeger, 2008), the dynamics of faculty culture (Clark, 1989), and the role of culture in doctoral student socialization (Gardner, 2008; Mendoza, 2007). Culture has historically been assumed to explain homogeneity in group processes (cf., Parsons, 1951) and underscore the either/or nature of group membership, particularly in regards to the socialization process. More recent scholarship highlights the collective influence of the individual and the organization related to the production of culture (Schein, 1993; Tierney, 1997; Tierney \& Rhoads, 1993; Weick \& Quinn, 1999). "Culture is not discovered by unchanging recruits," Tierney wrote (1997, p. 6), but rather negotiated as an active process of interpretation by organizational members.

Material published as part of this publication, either on-line or in print, is copyrighted by the Informing Science Institute. Permission to make digital or paper copy of part or all of these works for personal or classroom use is granted without fee provided that the copies are not made or distributed for profit or commercial advantage AND that copies 1) bear this notice in full and 2) give the full citation on the first page. It is permissible to abstract these works so long as credit is given. To copy in all other cases or to republish or to post on a server or to redistribute to lists requires specific permission and payment of a fee. Contact Publisher@InformingScience.org to request redistribution permission.
While culture has assumed a virtually paradigmatic status in higher education, the process by which individuals acquire and utilize cultural elements as organizational members is frequently left unexplored. The issue of how people determine which skills, beliefs, and behaviors to employ toward a particular end or action is of relevance for researchers interested in culture. The purpose of this 
article is to understand how doctoral students employ various aspects of culture as part of the socialization process. Building on the work of Tierney (1997), Schein (1993), and Weick (1995), culture is described as an active set of symbolic meanings and practices exhibited by members of a group (Swidler, 1986, 2001). Culture consists of elements that individuals selectively utilize to pursue various actions (DiMaggio, 1997; Peterson \& Anand, 2004), a perspective referred to throughout this article as a cultural repertoire (Swidler, 2001; Tilly, 1992). Swidler portrayed a cultural repertoire as "an oddly assorted tool kit containing implements of varying shapes that fit...more or less well, are not always easy to use, and only sometimes do the job" (2001, p. 24). The tools themselves are also artifacts which correspond to particular social and cultural contexts. Relying on case study data collected from an analysis of student socialization in a doctoral neuroscience program, this article focuses on the following research questions: How do doctoral students use cultural elements when engaging in curricular experiences? What role does culture play in mastering research skills? How does the use of culture impact identity development for doctoral students?

\section{The Composition and Influence of a Cultural Repertoire}

As presented by Swidler (1986) and Tilly (1992), culture consists of a repertoire of behaviors that includes symbols of meaning and practices selectively used by group members to construct "strategies of action" (Swidler, 2001, p. 284). From this definition, culture can be seen in a causal role; that is, the strategies of action pursued by group members are cultural products. Individuals pursue such strategies within unique social contexts, which influence decision making and behavior. The ritualistic practices and symbolic meanings held by a group provide individuals a means to organize reality. DiMaggio defined this perspective of culture as one that produces "less clustering of cultural elements among social groups, less strong linkages among the elements, and weaker pressures for the exclusion of inconsistent elements" (1997, p. 267). Groups are characterized by a degree of cultural heterogeneity, allowing individuals to selectively employ cultural resources related to behavior. Rather than a latent variable that underscores organizational homogeneity, or a blueprint to be transferred from one individual to another, culture is an active, dynamic metaphor for resources that individuals can put to strategic use.

Ultimately, people use culture to construct particular identities. In regards to knowledge shared among a particular community, Wolcott argued, "Whatever sense there is to be made [of this knowledge], we must make it ourselves. There is nothing about language or culture that renders them amenable to being possessed, gained, or put under control" (1991, p. 266). Culture is not something to be simply "picked up" by doctoral students over the course of their degree program. Instead, doctoral students develop a repertoire of behaviors as a means to use the culture. This interpretive, dynamic perspective on doctoral student socialization shifts research questions from how culture organizes individuals to how individuals organize culture (Eisenhart, 1988, p. 2).

By approaching culture as a series of actions performed by individuals, several significant components for research are brought to the fore. First, people utilize cultural tools in a variety of ways; previous definitions of culture have neglected the partial and various ways in which culture is used. Culture is not adopted wholesale by new recruits but is approached with varying levels of intensity and commitment at different times. The diversity of resources available which can be appropriated as part of the cultural repertoire, as well as the means to which these resources are used, is a crucial area for empirical analysis (Swidler, 2001). In addition, individual agency is considered as a counterpart to social structure. Individual behavior and interactions with others occur within the boundaries of a cultural repertoire as well as the boundaries of the institution. A mutual exchange exists between those practices perceived by the individual as privileged and the normative symbols of the dominant culture. This relationship ensures that the institution is more than simply the "sum of individual practices" (Hallett, 2003, p. 131). Rather, individuals bring 
various and evolving cultural repertoires into the organization, ensuring a connection between the group culture and individual expectations. For doctoral students, an inherent interplay exists between individual repertoires, the disciplinary and academic culture, and institutional structure.

In addition, individual behavior is not simply directed by cultural norms and values, but rather a cultural element itself. Viewed from an outsider perspective, behavior becomes the tool by which individuals develop relationships with peers, engage in cultural events, and position themselves as a group member. Swidler argued, "Codes influence action by ... defining the signs of membership in each category. Actors are then constrained by their knowledge, often implicit, of how their action will be read by others" (2001, p. 165). Cultural codes shape behavior by delimiting choices available to group members as well as giving a specific meaning to individual actions. Socialization, then, not only involves deciphering the environment in which particular actions occur, but also determining which strategies to employ as part of the environment. Academic work takes place in the intersection of multiple cultures, including the discipline, the department, the institution, and the profession (Becher \& Trowler, 2001; Holley, 2009; Kuh \& Whitt, 1988; Tierney, 1997). Doctoral students must negotiate those norms inherent to these multiple cultures. Table 1 outlines components of a cultural repertoire framework, noting examples related to doctoral student socialization. These components reflect on the existing body of literature related to socialization, in that culture is manifested through those codes that guide individual behavior and interactions. Semiotic codes constitute collective schemas as well as reflect various hierarchies of practices, all of which are embedded within particular communities. These components are not simply a reflection of the institutional arrangement, but also the experiences that individuals bring with them into the culture as well as the choices made once they are a member.

Table 1: Components of cultural repertoire

\begin{tabular}{|c|c|c|}
\hline Component & Definition & Example \\
\hline $\begin{array}{l}\text { Semiotic } \\
\text { codes }\end{array}$ & $\begin{array}{l}\text { Relationships of meaning that } \\
\text { are associated with institutional } \\
\text { arrangements }\end{array}$ & $\begin{array}{l}\text { Language used to describe concepts, ideas, and be- } \\
\text { havior specific to the discipline }\end{array}$ \\
\hline $\begin{array}{l}\text { Collective } \\
\text { schemas }\end{array}$ & $\begin{array}{l}\text { Widely understood and shared } \\
\text { templates that provide guide- } \\
\text { lines for behavior; enacted } \\
\text { through public rituals and } \\
\text { transmitted as beliefs and val- } \\
\text { ues }\end{array}$ & $\begin{array}{l}\text { - The content and arrangement of the doctoral curri- } \\
\text { culum, where students are required to master par- } \\
\text { ticular competencies before moving on to more } \\
\text { advanced tasks } \\
\text { - The requirements for qualifying exams and disser- } \\
\text { tations }\end{array}$ \\
\hline $\begin{array}{l}\text { Hierarchy of } \\
\text { practices }\end{array}$ & $\begin{array}{l}\text { Relationships between various } \\
\text { practices; some cultural prac- } \\
\text { tices organize, define, or con- } \\
\text { strain others }\end{array}$ & $\begin{array}{l}\text { - The emphasis given to research assistantships } \\
\text { compared to teaching assistantships }\end{array}$ \\
\hline Communities & $\begin{array}{l}\text { Utilization of cultural repertoire } \\
\text { develops identity, which is } \\
\text { reinforced by participation in } \\
\text { community of practice }\end{array}$ & $\begin{array}{l}\text { Application and admission to various academic } \\
\text { departments (such as biology as opposed to neu- } \\
\text { roscience) }\end{array}$ \\
\hline
\end{tabular}

\section{The Emphasis on Culture in Socialization Theories}

The existing literature regarding socialization in education has largely been based on a normative theory of culture. Culture is considered to be the primary influence in regards to student socialization. The acquisition of culture is one measure of student retention, satisfaction, and success. 
Golde (2000) defined socialization as a key component of doctoral student persistence. She noted that those students who were integrated into the disciplinary culture and invested in the cultural signifiers of success (such as active in research and publication) were more likely to persist. Weidman, Twale, and Stein (2001) identified institutional culture as inherent to the elements of socialization, including knowledge acquisition, involvement, interaction, and integration. In the case of graduate education, students engage in the disciplinary, departmental, institutional, and professional academic culture. Other scholars (Girves \& Wemmerus, 1988; Lovitts, 2001; Tinto, 1993) have reached similar conclusions, demonstrating that involvement in the academic department and with faculty members supported doctoral student degree progress and the acquisition of necessary skills, knowledge, and habits. Later work by Golde (2005) further explained how the unique departmental and disciplinary cultures can shape doctoral student persistence and satisfaction. A departmental culture that supports student research, scholarship, and participation facilitates socialization to academic norms (Weidman \& Stein, 2003). This normative approach highlights culture as an existing element of any community, one that is acquired by individuals through the process of socialization. Completion of the doctoral degree, in this example, requires successful engagement with the multiple layers of academic culture. Table 2 offers examples of recent scholarship on the process of socialization and the influence of culture.

Table 2. Recent scholarship regarding culture and doctoral student socialization

\begin{tabular}{|c|c|c|c|c|}
\hline Authors & Year & Research focus & Definition of culture & Implications \\
\hline $\begin{array}{l}\text { Weidman } \\
\text { and Stein }\end{array}$ & 2003 & $\begin{array}{l}\text { How doctoral students } \\
\text { are socialized to the } \\
\text { academic norms of } \\
\text { research and scholar- } \\
\text { ship in the various } \\
\text { disciplines }\end{array}$ & $\begin{array}{l}\text { Defined through peers (as } \\
\text { subcultures), the depart- } \\
\text { ment, and the institution } \\
\text { (through faculty); students } \\
\text { acquire culture through so- } \\
\text { cialization }\end{array}$ & $\begin{array}{l}\text { Participation and engagement in } \\
\text { the department fosters the acquisi- } \\
\text { tion of culture and effective socia- } \\
\text { lization }\end{array}$ \\
\hline \begin{tabular}{|l|} 
Gardner, \\
Hayes, and \\
Neider
\end{tabular} & 2007 & $\begin{array}{l}\text { An analysis of the } \\
\text { skills, habits, and dis- } \\
\text { positions needed to } \\
\text { complete a PhD in } \\
\text { education }\end{array}$ & $\begin{array}{l}\text { Defined as the sum of ac- } \\
\text { tivities in an organization; } \\
\text { students acquire such know- } \\
\text { ledge through socialization; } \\
\text { these values, beliefs, and } \\
\text { attitudes are specific to the } \\
\text { discipline }\end{array}$ & $\begin{array}{l}\text { Students acquire culture through } \\
\text { socialization, particularly in affec- } \\
\text { tive, cognitive, and behavioral do- } \\
\text { mains }\end{array}$ \\
\hline Gardner & 2008 & $\begin{array}{l}\text { The impact of culture } \\
\text { on the doctoral stu- } \\
\text { dent transition to an } \\
\text { independent scholar }\end{array}$ & None given & $\begin{array}{l}\text { Students experience culture } \\
\text { through faculty and peer relation- } \\
\text { ships as well as developmental } \\
\text { experiences }\end{array}$ \\
\hline Golde & 2000 & $\begin{array}{l}\text { A focus on socializa- } \\
\text { tion as related to doc- } \\
\text { toral student attrition }\end{array}$ & None given & $\begin{array}{l}\text { Integration into the departmental } \\
\text { and institutional culture is a crucial } \\
\text { influence on doctoral student attri- } \\
\text { tion }\end{array}$ \\
\hline Mendoza & 2007 & $\begin{array}{l}\text { How cultural know- } \\
\text { ledge is acquired by } \\
\text { doctoral students dur- } \\
\text { ing socialization }\end{array}$ & $\begin{array}{l}\text { Doctoral students acquire } \\
\text { culture according to the dis- } \\
\text { cipline and department } \\
\text { through socialization }\end{array}$ & $\begin{array}{l}\text { The promotion of a particular cul- } \\
\text { ture in a specific department fos- } \\
\text { ters specific outcomes for doctoral } \\
\text { students }\end{array}$ \\
\hline
\end{tabular}




\begin{tabular}{|l|l|l|l|l|}
\hline Authors & Year & \multicolumn{1}{|c|}{ Research focus } & \multicolumn{1}{|c|}{ Definition of culture } & \multicolumn{1}{c|}{ Implications } \\
\hline $\begin{array}{l}\text { Bair, Ha- } \\
\text { Worth, and } \\
\text { Sandfort }\end{array}$ & 2004 & $\begin{array}{l}\text { An analysis of the role } \\
\text { of faculty and student } \\
\text { affairs practitioners in } \\
\text { the socialization of } \\
\text { doctoral students }\end{array}$ & $\begin{array}{l}\text { The values, codes, rules, } \\
\text { myths, beliefs, symbols, } \\
\text { traditions, and practices that } \\
\text { orient and motivate students } \\
\text { and that give each program } \\
\text { its unique character and } \\
\text { meaning }\end{array}$ & $\begin{array}{l}\text { Faculty assume primary responsi- } \\
\text { bility for promoting a positive pro- } \\
\text { gram culture that is significant to } \\
\text { doctoral student development }\end{array}$ \\
\hline $\begin{array}{l}\text { Delamont, } \\
\text { Parry, and } \\
\text { Atkinson }\end{array}$ & 1997 & $\begin{array}{l}\text { How stability and } \\
\text { continuity in scientific } \\
\text { disciplines is sus- } \\
\text { tained through socia- } \\
\text { lization }\end{array}$ & $\begin{array}{l}\text { The "habitus" of a discip- } \\
\text { line, created and maintained } \\
\text { through pedagogic continui- } \\
\text { ty }\end{array}$ & $\begin{array}{l}\text { Socialization fosters tightly framed } \\
\text { transmission of cultural habitus } \\
\text { related to the discipline }\end{array}$ \\
\hline
\end{tabular}

The application of socialization to doctoral education frequently considers culture to be an implicit characteristic of social groups. From this perspective, culture is manifested as a set of rules that govern group behavior. Culture serves as a latent variable that forms the basis for communal organization. A homogenous culture is internally coherent, unchanging, and persistent, a "seamless web" shared by all members of the community. DiMaggio (1997, p. 267) defines the latent variable of culture as "a tight network of a few abstract central themes and their more concrete entailments, all instantiated to various degrees in a range of symbols, rituals, and practices." This network results in group members who share a limited number of consistent elements, such as beliefs, attitudes, and values. Members of a particular group are presumed to believe and act in specific ways. Because of the uniform nature of culture, any elements which run counter to the primary culture of the group are discounted or considered to be inconsistent. Those individuals who do not share the beliefs and actions of the group are excluded. Doctoral students either assimilate to the cultural norms through the process of socialization or drop out of their degree programs. Doctoral students in physics, for example, are socialized to the disciplinary culture of Physics, those students in chemistry to Chemistry, and so on. In its most basic formula, socialization requires the acquisition of culture, illustrated through the mastery and enactment of behavioral and cognitive norms.

\section{A Cultural Repertoire of Practices in Doctoral Education}

Individuals learn through engagement and observation of cultural activities. By acknowledging observation and participation as primary means of learning, learning is portrayed as a fundamentally situated event (Brown, Collins, \& Duguid, 1989). Students are embedded in activities that provide the means to acquire particular social and cognitive skills which are prioritized by the culture. Such activities may conform to formal pedagogic practices - the classroom lecture or seminar, for example. Other activities relate to unique disciplinary practices, such as research laboratories or conferences. Students share a range of information with their peers during informal social settings. Doctoral students typically work with faculty advisors as they acquire research skills in a laboratory or field setting. The practice of research is modeled on the behavior of the faculty mentor (Golde, Bueschel, Jones, \& Walker, 2006).

These experiences are filtered through individual values, beliefs, and attitudes. As Swidler (1986) argued, people prioritize behavior and beliefs for which they perceive themselves best suited. This participation is therefore shaped by individual characteristics, experiences, and expectations in regards to cultural practices. How people acquire culture is invariably related to the production of culture. Content, context, and the individual are intertwined influences in the development of a cultural repertoire (Eisenhart, 1988, 2001). Doctoral students progress through their degree pro- 
gram by achieving competencies in the particular culture of their discipline, program, or institution. Students develop competencies related to being a graduate student as well as an emergent professional in the field.

The role of the individual is stressed here, in terms of both agency and action. Individual values influence how people engage in various cultural activities. Swidler (1986, p. 284) concluded, "Values are an important piece of cultural equipment for establishing strategies of action, since part of what it means to have a strategy of action is to have a way of making the choices." Doctoral students use a cultural repertoire in a manner congruent to the perceived culture of their discipline, program, or institution. The accuracy of that perception, of course, influences a student's course of action. Each community of practice provides a context to define a cultural repertoire and select competencies of value. Doctoral student engagement with a research laboratory, for example, requires negotiation among the faculty and other senior researchers, peer lab colleagues, and external audiences. Informal social gatherings with peers and faculty foster shared dialogue and encourage problem solving in a casual setting (Golde et al., 2006). The repertoire is representative of the evolving sense of professional identity. Students also use this repertoire as they form relationships with faculty and peers - the repertoire is put into practice, through such ritualistic events as orientation, comprehensive exams, and dissertation defenses.

\section{Research Methodology}

Before I turn to an application of this framework to doctoral student socialization, I outline the research methods used for this study. The potential of ethnography to understand the influence of culture in educational settings has long been recognized by researchers (Delamont \& Atkinson, 1995; Gordon, Holland, \& Lahelma, 2001). Much of this research is based in the tradition of social interactionism, which prioritizes "the creation and change of symbolic orders... [and] an understanding of how people actually get through the day" (Gordon et al., p. 189). Through ethnographic methods, researchers seek to understand the cultural perspectives of a group of people related to ways of life, beliefs, or values. This study draws on selected traditions related to ethnography to document the culture of a doctoral neuroscience program at an elite American research university. A hallmark of such research is a focus on cultural concepts in data collection, analysis, and interpretation. These concepts include interactions between groups of people, the relationship to the physical and social environment, and the priority given to various goals, objectives, and values. I pursued this focus through a single-site qualitative case study, which enabled an analysis of interactions within a naturally bounded context (Merriam, 1998; Yin, 2003). I used three methods to collect data: 1) interviews with students and faculty, 2) observation of program events, and 3) document analysis.

\section{Data Collection}

I conducted individual and group interviews with students and faculty affiliated with the program. Student interviews served as the primary unit of analysis for the case study. Interviews with 40 doctoral students were supplemented by two student group interviews. The students were selected through stratified purposeful sampling (Miles \& Huberman, 1994) with the goal of including the range of individuals enrolled in the program. Over half of the students interviewed were women, and $33 \%$ were international students. The 40 respondents represented each stage of the program, ranging from those students enrolled in their first year of graduate school to students nearing year eight and the completion of the dissertation. The student interview protocol examined person$\mathrm{al} /$ demographic issues, including academic and professional background, motivations to enroll in the program, and the student's assessment of individual strengths and weaknesses; program/research experiences, such as influential faculty, coursework, and peers as well as challenging aspects of the program context; and the larger discipline of neuroscience. I drew upon the cul- 
tural repertoire framework to understand how students determined which strategies of action to employ in particular situations. For example, students were asked to describe experiences at various stages of the program as well as to identify the cultural meanings associated with those experiences. Faculty interviews supplemented the data collected from student interviews. Five faculty members were interviewed for the case study. One faculty respondent served as the director of the program. The other four professors were suggested by student contacts. The interview protocol for professors was designed to elicit responses related to the disciplinary culture from the faculty perspective. Questions focused on perceptions of student behaviors as well as definitions of success for doctoral students. All interviews were audiotaped and later transcribed, and lasted approximately one hour.

Observation data was gathered to document the experiences and processes inherent to affiliation with the program. From a student point of view, I focused on interaction in the laboratory and classroom. I gathered observation data regarding those students who had participated in either the individual or group interview. The students frequently gave me a tour of their laboratory work space or invited me to informal social events. My observations included the weekly seminar, faculty and administrative meetings, and meetings of the graduate student association. Thirty hours of program events were observed as part of this case study. Document analysis offered insight into cultural processes and symbols related to the neuroscience program. Primary documents included the graduate student orientation handbook, agendas from the annual program retreat, and the syllabi from the required first-year courses.

\section{Data Analysis}

Data analysis occurred through the definition and application of pattern codes to interview transcripts, fieldnotes, and program documents. Analysis through coding provided links across the range of data sources. The coding analysis was guided by components of the cultural repertoire identified earlier (Swidler, 2001). For this study, I treated the interview transcripts, fieldnotes, and documents as similar data forms, concentrating on themes, causal explanations, and relationships among people in terms of research practice, learning, and socialization (Miles \& Huberman, 1994). Guided by the assumption that interpretations of culture vary from individual to individual, I also considered those instances where different meanings were attached to the same experience as potentially rich sources of data. Codes were continually modified as new data was collected. I then defined themes that spanned across codes to create larger categories; these themes were used to outline the findings. In an effort to ensure trustworthiness, I performed member checks with the student and faculty participants. I shared emergent findings with the student focus groups and incorporated their feedback into the data. The multiple methods of data collection as well as participants ensured a range of perspectives regarding the program (Merriam, 1998).

\section{Research Context}

In order to understand how doctoral students define a cultural repertoire relevant to an academic department, I outline the contextual features of the neuroscience program featured in this study. The program is housed at an elite American research university that is a member of the American Association of Universities. Highly interdisciplinary in nature, the program is built through collaborative networks among 65 faculty from 18 different departments, programs, and colleges. Faculty and student research occurs in five different areas, representing multiple levels of neural analysis. Research foci include cell-molecular neurobiology, neural engineering, and computational neuroscience. Housed in a sleek, seven-story building near the center of campus, the program is lauded by institutional administrators as an example of the university's commitment to innovative interdisciplinary research and education. Such praise is not always evident, however, in the day-to-day practices of the program. For example, the sole program assistant works full- 
time for the biology department and is on "informal loan" to the neuroscience program. All of the faculty have full-time appointments in other departments and colleges on campus and spend varying amounts of time with doctoral students in the neuroscience program.

The curriculum for the program reflects the broad, interdisciplinary character of neuroscience; first-year students complete a shared core course and pursue an individualized program of study through disciplinary-based electives. Students work closely with those professors who teach the first-year core courses as well as individual faculty advisors. While students reference an inherent degree of competition among their peers for faculty attention and resources, they also note that the shared curriculum model and the array of research interests reduce the level of antagonism. The program boasts an annual retreat, where faculty and students gather for a weekend offcampus to discuss individual research accomplishments and program developments. For first-year students, this retreat serves as a formal introduction to the program and its members. The doctoral students participate in an active student organization, which hosts weekly socials, dinner with program faculty, topical seminars, and "how-to" sessions related to program tasks. The organization produces an orientation handbook, which gives advice on coursework and requirements. A more informal handbook also exists that provides satirical commentary on the various faculty and program courses.

\section{Findings: Defining the Cultural Repertoire}

My intent is to understand how doctoral students employ various aspects of culture as part of the socialization process. By analyzing doctoral student experiences through the lens of a cultural repertoire, a greater understanding of individual agency, action, and practice can be gained. I organize the data by the three research questions which guided this study: How do doctoral students use cultural elements when engaging in formal classroom experiences? What role does culture play in mastering research skills? How does the use of culture impact identity development for doctoral students?

\section{Components of Culture: Curricular Learning Experiences}

While doctoral programs are largely concentrated on fostering the independent skills of research and knowledge production (Lovitts, 2005), the formal academic curriculum, including core classes and seminars, is significant to student development. From this perspective, the curriculum is a cultural artifact of relevance to the patterns of behavior and meaning important to the group. The debate over knowledge as either objective (and therefore not dependent on context) or subjective (and therefore dependent on context) is not one I enter here; rather, I consider that, as a community of practice, the disciplines are defined by a situated curriculum with which doctoral students engage. The curriculum of a doctoral program is an explicit structure for organizing student knowledge and cultural engagement.

Students shaped their curricular experiences based on their academic and professional backgrounds as well as their interaction with the institutionalized structure. The handbook provided to doctoral students in the neuroscience program affirms the importance of the curriculum and states the programmatic goals of such courses. The handbook explains, "The philosophy behind the curriculum is to get students into research as soon as possible, and provide them with the best tools to perform it." This message was reinforced by other symbols: the annual retreat where first-year students listened to the research accomplishments of faculty and advanced peers; the weekly seminars where various professors talked about their research; and the annual student research fair sponsored by the graduate student organization. The curriculum was largely valued for the knowledge which could be applied to research and its role as a required element of degree completion. 
Doctoral students connect the knowledge of the discipline with previous learning experiences. Such connections form the basis of the cultural repertoire. Renee, a first-year doctoral student, reflected on her undergraduate experiences in a psychology program. "I felt like the theories were just pulled out of thin air," she said. "You take general classes about famous psychologists who are sprouting their theories, and you think...why? Where is your proof? Your data?" She identifies her experiences as an influence on her approach toward the core curriculum in the doctoral program. As part of her repertoire of behavior, she continually sought clarification and connections between ideas presented in class. "I want information with more substance, with more data, something I can really sink my hands and feet into. I want to be able to back up everything with observations and data," she said. For Renee, acquiring the knowledge canon presented during the first-year curriculum required a connection to empirical data analysis and "proof." Dan, another student in the first year of the program, identified the influence of his engineering interests on the study of cells. Dan completed an undergraduate degree in engineering. "I think of the cell as a mechanical system," he explained. "The way cells make energy is through these pores-actually a spinning kind of a mechanism, a generator that produces energy. And so I have always liked the idea of that mechanical kind of thing, opening, turning, shifting, changing," he concluded. He contrasted his theoretical perspectives with those of his advisor, who he described as "more purely a biologist." Even during the first year of the program, Dan distinguished his identity by his approach to knowledge. His emergent identity shaped his perception of the competencies he brought into the program.

The program encourages innovative, individualistic approaches to knowledge production and acquisition. As Dr. Hutchinson, a longtime professor in the program, explained, the admissions committee targets students from a diverse range of academic backgrounds who demonstrate intellectual aptitude. Renee's focus on empirical data and Dan's interest in the mechanical nature of cells both compliment the cultural focus of the program. According to the perspective of doctoral student socialization as the active construction of a cultural repertoire, the curriculum in the neuroscience program provides tools for students to use in diverse ways. Dr. Mangis, a faculty member in psychology, explained, "Doctoral students come into the neuroscience program with a really wide array of backgrounds, so the core courses give them a common foundation to work from." From this starting point, students use such knowledge to become particular kinds of people-in this case, to become particular kinds of neuroscientists. Not only is the knowledge shaped by the individual, but knowledge is also shaped by the context.

Students highlighted the primary textbook required for the first-year core course as a standard for their language, behavior, and knowledge. "There are three hundred pages of what you need to know about neuroscience," Jennifer, a second-year student, commented. Such knowledge served to differentiate the doctoral students in neuroscience from those in neighboring disciplines. Amanda, a first-year doctoral student in the neuroscience program, explained, "I will need to know those vocabulary words [from classes] in seminars and meetings...to be able to say I know neuroscience, I need to know all those little things." Amanda's research interests overlapped with several other disciplines. Several of her peer colleagues in the research laboratories were enrolled in other degree programs at the university, particularly psychology and biology. Amanda explained that the knowledge she gained from the core neuroscience curriculum would "set [her] apart" from students in those disciplines. As a compliment to individual agency, the social context shaped Amanda's perception of the knowledge considered of value to neuroscientists.

Departmental culture exists through the actions and beliefs of the participants as well as the context of the institution and the program. The institutional structure prioritizes meanings and behavior related to the culture. Doctoral students reported the cultural emphasis on research, grant writing, and publication on a programmatic and institutional level. The university where this study was conducted defines itself as "one of a small number of [American] premier research in- 
stitutions," and prioritizes the development of future faculty and researchers in its graduate programs. In the case of the neuroscience program, such priorities were operationalized through research.

Instead of an extensive curricular requirement, students were expected to engage in laboratory research starting from their first semester. Students were consequently expected to prioritize research activities. Dr. Jones, a professor in the program, said, "My strategy is to make my students famous as fast as possible. And you only do that by being in the lab and getting out good research." Another professor, Dr. Williamson, added, "We want our students to be able to practice good science, in the lab." Students developed strategies in response to the programmatic emphasis on research activities. "[The program] expects us to be in the lab a lot," Jason, a second-year student, explained. Allison, a first-year student, stated, "This program doesn't really put a lot of emphasis on class learning. You should be spending your time in your lab and not worrying about class." Numerous students supported the conclusions of Roberta, who was in her second year of the program: "What is even more important [than class] is when you get into the lab, that you understand what is going on in your lab individually. As long as you learn the basics and the techniques and the meanings behind your lab, then you're fine." Students devise strategies of action in response to the emphasis on laboratory learning. Multiple students recounted late evenings and weekends conducting research in the laboratory.

\section{Components of Culture: The Practice of Research}

Engagement in research remains a necessity for membership in the disciplinary community for doctoral students. The practice of research requires a range of competencies, including the use of formal instruments and specialized language. Such practices reflect the innumerable research topics and behaviors prioritized by the disciplines. In graduate programs, students gain knowledge, literacy, and skill in the language and behavior necessary for research. Just as the formal curriculum of the program occurs through situated learning, so is the practice of research contingent and contextual. Students engage in behavior that is responsive to the context as well as aligned with the individual's cultural repertoire. While the practice of research may vary according to the disciplines, commonalities exist between students in doctoral programs, including the skills of inquiry, observation, and analysis.

Research serves as a central component of the neuroscience program. Doctoral students engage in a formal class curriculum that is designed not only to provide them with the core knowledge of the discipline, but also to equip them for research practices. Most of the doctoral students assume research assistantships upon enrolling in the program. The program handbook explains, "At a minimum, a RAship should be considered a 20 hour a week job. Students usually opt to put in more time, however, depending on the relationship between RA duties and the dissertation or the likelihood of co-authoring resulting publications." The program advocates for research over teaching assistantships, noting that "[Students] are here primarily to do research, not teach." The program's message to students is conveyed in the last few paragraphs of the program handbook: "Presumably you decided to come to graduate school because you wanted to do research....research will quickly become your first priority." Students responded to this cultural logic. Lawrence, a second-year student, succinctly explained, "The point of the Ph.D. is to become a researcher." After the required curriculum of the first year, students are expected to become immersed in their research activities.

Identifying a research laboratory and faculty advisor influences a student's research agenda over the course of the doctoral program. The process of selecting among a range of laboratories is one means by which students identify resources as part of their cultural repertoire. The active selection of the lab allows students to define their participation in the community. The institutional and disciplinary context is of significance here. "Most of our research is driven by a focus on having a 
positive effect on human health," said Ivana, who recently defended her dissertation. "That is the intent of a lot of people in neuroscience research." Within this disciplinary emphasis on human health, however, students shaped their research agendas based on interactions with faculty and personal motivations. "I always wanted to do research," noted Kevin, a first-year student. "I found the professor [at this university] who I'm working with now. I really made a connection with her and her work." Cassandra, a second-year student, added, "[Working with my professor], I feel really secure. My research is built on something with good foundations, and [the lab] is getting to something that is the big jumping off point for bigger things."

Students develop their identities through engagement in research, fostered by the program as a series of three required laboratory rotations during the first year. At the end of that time, students are required to permanently select a research advisor for the remainder of the program. The rotations offer a sense of embedded practice, and student agency determines individual participation. The long-term influence of research laboratories is significant. As students progress through the program, they construct a professional identity in relation to their research topic and colleagues. "I think I need to stay doing the same research for awhile," said Candace, a recent graduate who was looking for a faculty position. "It's too hard to be an expert in this and have to go back to ground zero for another technique or topic." For Candace, participation in the laboratory fosters the identity of an "expert." In her second year of the program, Cassandra explained, "Last year, my concepts were not totally grounded, but once I got [to the lab], everything started to fit. Working on the techniques made me comfortable being in the lab, and now I feel like it is my second home."

Part of a cultural repertoire is the significance of experience as a means to frame meaning. The "culture" of the neuroscience program is one framed by student interpretations. For example, Melinda, who is completing her dissertation, studied psychology as an undergraduate student. "The research wasn't scientific enough for me, so I got into biology, something more scientific," she explained. Melinda's perception of scientific research as a specific type of activity that involves certain behaviors determined her strategies of action as a student in the neuroscience program. Other students identified research practices that aligned with their sense of identity. Using animals for research practices was a common occurrence for laboratories associated with the neuroscience program. As a cultural symbol, animal research was an ordered component of the program's cultural logic, and one of which many students felt unsure. Elizabeth, whose father works as a biologist, said, "I thought I was used to animal research. But it is such a strange feeling. I just can't do it." Elizabeth identified a research laboratory that did not use animals for experimentation as her permanent lab.

\section{The Influence of Culture on Doctoral Student Identity Development}

If culture is fragmented among different groups and inconsistent in its application (DiMaggio, 1997), then faculty and peers play a decisive role in how students come to perceive of the "neuroscience culture." Michael, who recently defended his dissertation, explained, "I chose this program specifically because my research interests overlapped with one of the researchers here." As students work closely with faculty advisors, the individual perception of culture becomes more consistent with research topics. Diana, a fourth-year student, noted, "Once I got to know and understand where [my advisor] was coming from, and what his past research means, I am starting to see interesting things, what is going on, his bigger plans." Working with faculty provides the means for schematic organization of the culture for students.

Faculty and peers serve as social actors through which students order cultural elements in order to fulfill strategies of action. Identifying faculty as cultural hallmarks can create disconnect for students, particularly when research interests and perspectives are not aligned. "You think the pro- 
fessors should know everything," explained Christy, a second-year student. "When you want to talk to them about something you are working on, but they are not, they say they can't help you, that it is not their area." Students also recognize peers as significant cultural barometers and share identities with those students who construct similar strategies of action. "It is kind of hard sometimes, talking to [other students] - your research doesn't even meet and you don't even have a similar experience," James, a third-year student, commented.

Students developed competencies specific to the culture of the neuroscience program. Such repertoires allowed them to pursue strategies of action that differentiated their skills from peers in other disciplines. In constructing a particular identity as a neuroscientist, students developed skills that marked membership in a group. This social construction of identity is fostered by individual agency and action. Significant to the cultural repertoire is not only how students defined knowledge as part of the competencies necessary for participation in the culture, but also how such competencies could be contrasted to other cultures. Students develop and utilize cultural skills that not only distinguish their identity as a neuroscientist, but also differentiate various groups. Strategies of action, which can be defined as cultural products, are specific to different cultural groups. Victor, a second-year student with a background in engineering, explained his difficulties in understanding biological concepts. He compared his experiences with a classmate who previously studied biology. "I would try to memorize, but you can't memorize the whole body. He said that you have to understand the whole circuit diagram, that this organ becomes active and activates another, and you remember the chain, rather than memorizing everything," he said. Victor's frustration characterized his entire learning experience in the course. He left with a strong perception of his learning style compared to his peers with different cultural repertoires. Victor concluded, "I believe there is a huge difference between the way biologists think and the way engineers think."

This distinction was not always clear. For example, Stephanie worked in a lab focused on the role of estrogen in degenerative diseases. She explained, "Everything we covered in the core curriculum, I should know as a neuroscientist, but you never know what will happen in your research, and you might end up needing information outside of your area." Ultimately, Stephanie's perception of the expanse of knowledge needed to practice neuroscience was not congruent with that of the program curriculum. "I understand we are general neuroscientists, but most of us will be doing molecular techniques and genetic techniques... these are very important for all scientists to have as a foundation. It was not even covered [in the curriculum]." While people use culture to construct their identities, they also use culture to shape a repertoire of behavior, skills, knowledge, and habits reflective of the group to which they belong. This repertoire is dependent on both individual perception (how I see myself) and perception of others (how I see people other than myself). Therefore, culture is influenced not only by the knowledge perceived as valuable within the culture of the neuroscience program, but also the knowledge perceived to be unique solely to the neuroscience culture.

\section{Discussion}

In this study, I considered how doctoral students in a neuroscience program employed various aspects of culture as part of the socialization process. By utilizing resources associated with a repertoire of skills, language, and beliefs, individuals use culture to learn how to be particular kinds of people. Since doctoral education serves as socialization for membership in an institutional and disciplinary community, defining strategies of action occurs in the context of a community of practice. This practice is bound by the multiple layers of culture, including the academic department, the discipline, the institution, and the profession. Students share such logic in terms of what it means to become a scholar and the central role of such activity in their doctoral experiences. This logic is not always a patterned guide to behavior. While often strategies of action are shared 
among groups of individuals working together in a research laboratory or collaborative group, the process of individual negotiation distinguishes socialization.

The cultures into which people are socialized offer the opportunity for various choices. Accordingly, culture develops not from the larger discipline, but rather the inverse - culture results from active engagement between students, faculty, and peers in the program. This definition stresses the multiple and often competing choices students feel forced to make, such as the student's decision to work with animal models in research. An emphasis on individual interpretation of institutional culture allows researchers to determine the nature of identity and behavior in shaping the context. Understanding doctoral student socialization requires the understanding that students make individual decisions that shape their experiences and membership in disciplinary culture. This perspective acknowledges the heterogeneity that defines organizations as well as the range of individual commitment to various communities. By identifying culture as an active individual process, researchers focus on those people who utilize the culture, and ask how individuals chose behavior, meaning, and beliefs among the range of meanings available to them.

Two areas of future research could provide an enhanced understanding of the cultural repertoire and its relation to doctoral student socialization. International students likely bring a range of cultural repertoires into their doctoral programs. While the sample included a number of international doctoral students enrolled in the neuroscience program, a more detailed analysis specific to international students would provide further depth to this question. Other demographic characteristics such as gender, race/ethnicity, and socio-economic status might also provide greater insight into how doctoral students experience the socialization process. Since the cultural repertoire serves as a filter by which the program is experienced, this study's conclusions suggest that these individual characteristics are impactful. In addition, doctoral students experience socialization to multiple layers of culture. Future research should consider how these multiple cultures interact, and what impact this interaction has on the development of a cultural repertoire by doctoral students.

The elements of the cultural repertoire framework identified earlier offer guidelines for improving socialization practices. For example, semiotic codes exist between group members that communicate meaning within the culture. These codes are impacted by students' previous academic and professional experiences. For Renee, the skills acquired through the first-year curriculum were filtered through her background in psychology. This background gave emphasis and meaning to "scientific" forms of knowledge, and impacted Renee's perception of the neuroscience culture. Not only was the culture a contrast to psychology, but it also privileged certain skills and knowledge. Other students noted the prestige afforded to research practices and quickly developed an identity congruent with their advisor's laboratory and topic. These elements offered a sense of belonging to the discipline. As a result, culture should not be viewed as a passive practice, but rather the act of active interpretation and negotiation. Participation in a community of practice assumes that culture is produced by individuals who share a common interest and pursue these interests through unique strategies of action.

Doctoral students do not acquire all elements of the culture presented to them over the course of their program. They selectively engage with those elements perceived to be aligned with their individual repertoires. Related to the framework of the cultural repertoire is how doctoral students make social, cognitive, and behavioral choices distinct from peers in other disciplines. A consistent theme throughout the student interviews was how possessing a certain element of knowledge or engaging in a particular research topic was unique to the discipline of neuroscience. This finding raises the question of how doctoral students acquire these sorts of information, and to what degree they persist in their beliefs over the course of the doctoral program. The program culture was manifested through those faculty and students who worked on prestigious, grant-funded research topics, centrally located in the main neuroscience building. Those students in the study 
who worked on a research topic that was perceived to be on the periphery of the "neuroscience culture" often felt a sense of disconnect from their peers.

An analysis of student responses in this study reveals culture as a dynamic process as well as one that varied from individual to individual. In many ways, the disciplines are enriched by fostering this sort of diversity. The wealth of ideas and interests that can be encompassed under the disciplinary umbrella add to the depth of knowledge within the field. Aligning individual strengths with those ideas inherent to the discipline is a key consideration for doctoral student socialization. This study, however, underscores the importance for students of making well-informed choices in regards to pursuit of doctoral education. Not only should the choice of institution be closely considered, but issues of curriculum and research topics also impact a student's engagement with the disciplinary culture. Some students in the study did not perceive the expectations, skills, and knowledge they brought into the program to be of value to other community members, resulting in a weak connection to faculty and peers. This weak connection persisted to the level of the discipline and its culture.

This study provides supporting evidence for the significance of culture to doctoral student socialization. How students experience their degree program and the impact of the program on their development is related to the discipline, the department, and the institution. Decades of research related to this population show that doctoral students must be actively engaged in the multiple facets of academic life to complete their degree program. The application of the cultural repertoire framework, however, provides researchers with additional tools for understanding the complexity of this process. Socialization does not occur as a wholly deterministic relationship between students and the larger discipline. Rather, culture should be viewed as a paradox of experiences that simultaneously constrain and limit behavior, but are enabling and flexible in their application.

\section{References}

Bair, C., Haworth, J., \& Sandfort, M. (2004). Doctoral student learning and development: A shared responsibility. NASPA Journal, 41(4), Art. 7. Retrieved March 18, 2008, from http://publications.naspa.org/naspajournal/vol41/iss4/art7

Becher, T., \& Trowler, P. (2001). Academic tribes and territories: Intellectual inquiry and the culture of the disciplines ( ${ }^{\text {nd }}$ ed). Philadelphia, PA: SRHE/Open University Press.

Bertram Gallant, T. (2007). The complexity of integrity, culture, and change: A case study of a liberal arts college. The Review of Higher Education, 30(4), 391-411.

Brown, J., Collins, A., \& Duguid, P. (1989). Situated cognition and the culture of learning. Educational Researcher, 18, 32-42.

Clark, B. (1989).The academic life: Small worlds, different worlds. Educational Researcher, 18(5), 4-8.

Delamont, S., \& Atkinson, P. (1995). Fighting familiarity: Essays on education and ethnography. Cresskill, NJ: Hampton Press.

Delamont, S., Parry, O., \& Atkinson, P. (1997). Critical mass and pedagogic continuity: Studies in academic habitus. British Journal of Sociology of Education, 18, 533-549.

DiMaggio, P. (1997). Culture and cognition. Annual Review of Sociology, 23, 263-287.

Eisenhart, M. (1988). The ethnographic research tradition and mathematics education research. Journal for Research in Mathematics Education, 19(2), 99-114.

Eisenhart, M. (2001). Educational ethnography past, present, and future: Ideas to work with. Educational Researcher, 30(8), 16-27. 
Gardner, S. (2008). "What's too much and what's too little?" The process of becoming an independent researcher in doctoral education. Journal of Higher Education, 79(3), 326-350.

Gardner, S., Hayes, M., \& Neider, X. (2007). The disposition and skills of a Ph.D. in education: Perspectives of faculty and graduate students in one college of education. Innovative Higher Education, 31(5), 287-299.

Girves, J., \& Wemmerus, V. (1988). Developing models of graduate student degree progress. Journal of Higher Education, 59(2), 163-189.

Golde, C. (2000). Should I stay or should I go? Student descriptions of the doctoral attrition process. Review of Higher Education, 23(2), 199-227.

Golde, C. (2005). The role of the department and discipline in doctoral student attrition: Lessons from four departments. Journal of Higher Education, 76(6), 669-700.

Golde, C., Bueschel, A., Jones, L., \& Walker, G. (2006). Apprenticeship and intellectual community: Lessons from the Carnegie Initiative on the Doctorate. Paper read at the Doctoral Education and the Faculty of the Future conference, Cornell University, Ithaca, New York.

Gordon, T., Holland, J., \& Lahelma, E. (2001). Ethnographic research in educational settings. In P. Atkinson, A. Coffey, S. Delamont, L. Lofland, \& J. Lofland (Eds.), Handbook of ethnography (pp. 188203). Thousand Oaks, CA: Sage Publications.

Hallett, T. (2003). Symbolic power and organizational change. Sociological Theory, 21(2), 128-149.

Holley, K. (2009). Animal research practices and doctoral student identity development in a scientific community. Studies in Higher Education, 34(5), 331-344.

Kezar, A., \& Eckel, P. (2002). The effect of institutional culture on change strategies in higher education: Universal principles or culturally responsive concepts? Journal of Higher Education, 73(4), 435-460.

Kuh, G., \& Whitt, E. (1988). The invisible tapestry: Culture in American colleges and universities. San Francisco, CA: Jossey Bass.

Love, P. (1997).Contradiction and paradox: Attempting to change the culture of sexual orientation at a small Catholic college. The Review of Higher Education, 20(4), 381-398.

Lovitts, B. (2001). Leaving the ivory tower. Lanham, MD: Rowman \& Littlefield.

Lovitts, B. (2005). Being a good course-taker is not enough: A theoretical perspective on the transition to independent research. Studies in Higher Education, 30(2), 137-154.

Mendoza, P. (2007). Academic capitalism and doctoral student socialization: A case study. Journal of Higher Education, 78(1), 71-96.

Merriam, S. (1998). Qualitative research and case study applications in education. San Francisco: Jossey Bass.

Miles, M., \& Huberman, A. (1994). Qualitative data analysis ( $2^{\text {nd }}$ ed). Thousand Oaks, CA: Sage.

Parsons, T. (1951). The social system. New York: Free Press.

Peterson, R., \& Anand, N. (2004). The production of culture perspective. Annual Review of Sociology, $30(1), 311-334$.

Schein, E. (1988). Organizational culture. Working paper \#2088-88. Boston: Sloan School of Management, Massachusetts Institute of Technology.

Schein, E. (1993). On dialogue, culture, and organizational learning. Organizational Dynamics, 21, 40-51.

Swidler, A. (1986). Culture in actions: Symbols and strategies. American Sociological Review, 51(2), 273286.

Swidler, A. (2001). Talk of love: How culture matters. Chicago: University of Chicago Press. 
Thornton, C., \& Jaeger, A. (2006). Institutional culture and civic responsibility: An ethnographic study. Journal of College Student Development, 47(1), 52-68.

Tierney, W. (1988). Organizational culture in higher education: Defining the essentials. Journal of Higher Education, 59(1), 1-21.

Tierney, W. (1997). Organizational socialization in higher education. Journal of Higher Education, 68(1), $2-21$.

Tierney, W., \& Rhoads, R. (1993). Enhancing promotion, tenure, and beyond: Faculty socialization as a cultural process. ASHE-ERIC Higher Education Report, (6). Washington, DC: George Washington University.

Tilly, C. (1992). How to detect, describe, and explain repertoires of contention. Working paper 150. New York: Center for the Study of Social Change, New School for Social Research.

Tinto, V. (1993). Rethinking the causes and cures of student attrition $\left(2^{\text {nd }}\right.$ ed). Chicago, IL: University of Chicago Press.

Valimaa, J. (1998). Culture and identity in higher education research. Higher Education, 36(2), 119-138.

Weick, K. (1995). Sensemaking in organizations. Thousand Oaks, CA: Sage Publications.

Weick, K., \& Quinn, R. (1999). Organizational change and development. Annual Review of Psychology, $50,361-386$.

Weidman, P., \& Stein, E. (2003). Socialization of doctoral students to academic norms. Research in Higher Education, 44(6), 641-656.

Weidman, P., Twale, D., \& Stein, E. (2001). Socialization of graduate and professional students in higher education: A perilous passage? ASHE-ERIC Higher Education Report, 28. San Francisco: JosseyBass.

Wolcott, H. (1991). Propriospect and the acquisition of culture. Anthropology \& Education Quarterly, 22(3), 251-273.

Yin, R. (2003). Case study research: Design and methods ( $3^{\text {rd }}$ ed). Thousand Oaks, CA: Sage Publications.

\section{Biography}

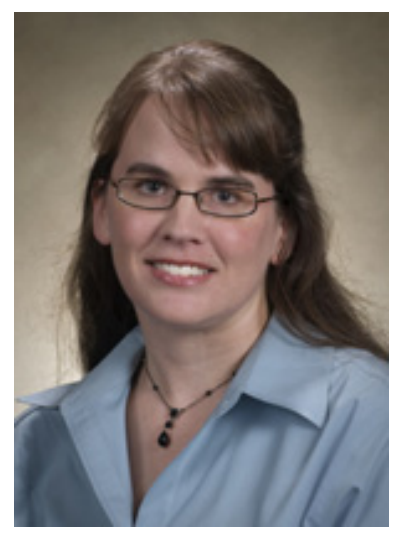

Karri A. Holley is assistant professor of higher education at the University of Alabama. She received her Ph.D. from the University of Southern California. Her research interests include graduate and professional education, interdisciplinarity, and qualitative inquiry. Her work has appeared in Higher Education, Educational Researcher, Studies in Higher Education, and Journal of Student Affairs Research and Practice. 